\title{
The problem of the compatibility of bitumen sheets for the reconstruction and rehabilitation of roofs
}

\author{
Jan Plachý1,** \\ ${ }^{1}$ Institute of Technology and Business in České Budějovice, Department of Civil Engineering, \\ 370 01, České Budějovice, Czech Republic
}

\begin{abstract}
During the renovation of flat roofs, the waterproofing layer is often repaired locally rather than completely replaced. When making such repairs, it is very important to know whether the proposed bitumen sheets are compatible in order to prevent delamination and the release of the joints. This paper deals with the determination of the resistance of bitumen sheet joints against peeling when combined with different bitumen materials. On the basis of the described test methodology it was possible to determine whether the selected bitumen materials were compatible with bitumen sheets. As part of the experiments, modified bitumen sheets with plastomers (PO), oxidized bitumen (OX), and elastomers (SBS), were tested.
\end{abstract}

\section{Introduction}

Many problems associated with roof cladding are related to the release of the bitumen sheet joints. This paper deals with the determination of the resistance of bitumen sheet (AP) joints against peeling [1].

During the renovation of flat roofs, the waterproofing layer is often repaired locally rather than completely replaced. When making such repairs, it is very important to know whether the proposed bitumen sheets are compatible in order to prevent delamination and the release of the joints. In this study, for experimental purposes, bitumen sheets with various kinds of coatings were therefore combined. At present, the coatings on bitumen sheets (AP) are often modified with polymers of either a plastomer or elastomeric nature. This poses a problem with regards to AP joints. From the viewpoint of the chemical composition, it is not always compatible to join sheets with a modified coating made from certain types of polymers of the plastomer type and an asphalt mass modified with elastomeric polymers.

The advice from manufacturers and suppliers with regards to the combination of bitumen sheets (AP) with a modified coating of a plastomer character with other types of coating materials, varies. Some say it is possible, whereas others advise against it or state

\footnotetext{
* Corresponding author: plachy@mail.vstecb.cz
} 
that it is prohibited. The compatibility depends directly on the type of polymer used in coating.

At present, the identification and labelling of modified bitumen sheets of a plastomer nature is inaccurate. Within this context, the terms APP and SBS require closer attention. SBS is a modification of an elastomeric nature, which is represented by the copolymer of styrene - butadiene-styrene. In contrast, APP is a modification of a plastic nature.

Up to the present day, the use of polymers for SBS modification has remained almost unchanged. The only differences between the individual types of polymers is the proportion of styrene and the diblock number of styrene-budadien. This differs to the situation with regards to the polymers which are labelled as APP. The APP labelling applies to atactic polypropylene, which results in the production of isotactic polypropylene (IPP). At present, APP is only used marginally in production. Polymers from the group of polyolefins (PO) are used as a modifier in the bitumen mass. These polymers are primarily manufactured for the production of modified bitumen. Such modified bitumen is either used for roofs or roads. The mechanical parameters and the quality of the bitumen mass made of PO is higher [2]. The peel strength in polymers of primary chemical synthesis - polyolefins (PO) is comparable to the bitumen mass modified with SBS. In secondary chemical synthesis the peel strength of APP is lower by approximately $30 \%$. Not all manufactures use PO. It is for this reason that some bitumen sheets (AP) of a plastomer nature are problematic and others are not.

A number of authors [2-7] have dealt with the shear and peel resistance of joints. The latest author to do so, produced very similar results [8]. The strength of joints has been compared to AP joints with a coating modified with SBS and sheets with a coating from oxidized bitumen. The strength of the joints of AP with APP were much lower. The strength of sheets with a coating modified with APP, peeled at room temperature, was 25 to $50 \%$ of the strength of bitumen sheets with a coating modified with SBS. A principle of ageing bitumen mass with modification SBS is given for an overview [4].

SBS copolymers belong to the group of block copolymers, whereas APP to the group of polyolefins. In the case of SBS copolymers, it forms a mixture with the bitumen, which due to its aromatic form with bitumen (styrene is aromatic in nature) creates a threedimensional physical network between the polystyrene blocks in the bitumen. Its mechanical properties and stability over time are determined by the three dimensional physical network, wherein the butadiene bond ensures the elasticity of the entire polymerbitumen mixture. Ageing over time due to exposure to climatic conditions, leads to the decoupling of the bonds and thus to a loss of its elastic properties.

In the case of APP modifications, and polymers in general from the group of polyolefins, the chemical relationship with bitumen is considerably smaller. APP (polyolefins) makes an emulsion with bitumen. Over time, a separation occurs in each phase (between the bitumen and the polymer) which is caused by their different surface tensions. It is also caused by the different molecular sizes of the two phases and their mobility. This separation results in the strength reduction that occurs at the joints.

\section{Materials, testing methodology and assessment}

For the actual tests six sample combinations were prepared from AP with a modified coating from SBS, PO, or oxidized bitumen (OX). The combinations were as follows: $\mathrm{SBS}+\mathrm{SBS}$; SBS+OX; SBS+PO; PO+PO; OX+OX.

The tests were conducted at a room temperature of $+23^{\circ} \mathrm{C}$ and in part at $+50^{\circ} \mathrm{C}$ for capacity reasons and on the basis of previous results $[2,3]$. The tests at $+50^{\circ} \mathrm{C}$ were not carried out in a climatic room. The number of samples of the aforementioned combinations was determined to be five in accordance with the methodology in [1]. A frame shift of a 
load machine is according to [1] to $100 \mathrm{~mm}$ per minute. The test samples (TS) were clamped into the jaws of the testing body (see Figure 1). The low numbers of test samples (TS) place very high demands on the preparation of its own TS. The actual tests were carried out after thermal ageing at $70^{\circ} \mathrm{C}$ after 0 (new), 2, 4, and 8 weeks. The evaluation was only conducted for the maximum force $\mathrm{F}_{\max }$.

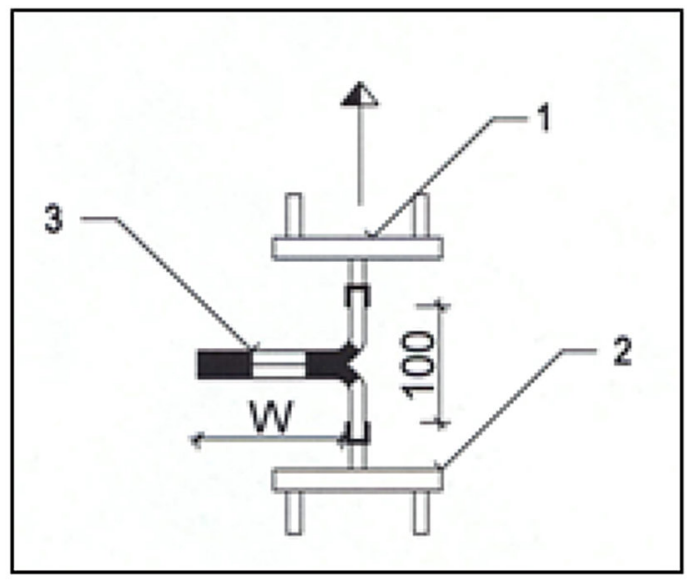

Fig. 1. Strength testing of joints against peeling according to [1]. 1 - frame of testing machine; 2 clamp of the testing body; 3 - bitumen sheet joint. Source: Author.

5 test samples of the determined combinations were used for testing. The final force is presented in the form $\bar{x} \pm \bar{\vartheta}(\bar{x})$, where $\bar{x}$ is the arithmetic average and $\bar{\vartheta}(\bar{x})$ is the probable measurement error. The latter was determined on the basis of the error theory for deviations in the arithmetic average using the formula:

$$
\bar{\vartheta}(\bar{x})=\frac{2}{3} \sqrt{\frac{1}{n(n-1)} \sum_{i=1}^{n}\left(x_{i}-\bar{x}\right)^{2}} .
$$

\section{Results}

Table 1. Laboratory measurements of AP joint peel resistance for different types of coating - $\mathrm{F}_{\max }$ $(\mathrm{N} / 50 \mathrm{~mm})$

\begin{tabular}{|c|c|c|c|c|c|}
\hline \multicolumn{2}{|c|}{ Test samples } & \multicolumn{4}{|c|}{ Mean value of peel resistance of the joints F max (N / 50 mm) at } \\
$23^{\circ} \mathrm{C}$ \\
\hline $\begin{array}{c}\text { Type of mass } \\
\text { bitumen } \\
\text { coating }\end{array}$ & $\begin{array}{c}\text { Ageing at } 70^{\circ} \mathrm{C} \\
\text { (weeks) }\end{array}$ & $\begin{array}{c}\text { The mean } \\
\text { value }\end{array}$ & Probable error & $\begin{array}{c}\text { Standard } \\
\text { deviation }\end{array}$ & $\begin{array}{c}\text { Coefficient of } \\
\text { variation (\%) }\end{array}$ \\
\hline \multirow{4}{*}{ SBS+SBS } & 0 & 2228 & 12.0 & 40.3 & 18.1 \\
\cline { 2 - 6 } & $0\left(50^{\circ} \mathrm{C}\right)$ & 54.9 & 4.8 & 16.0 & 29.2 \\
\cline { 2 - 6 } & 2 & 189.6 & 5.3 & 16.0 & 8.5 \\
\cline { 2 - 6 } & 4 & 218.5 & 5.9 & 17.6 & 8.1 \\
\cline { 2 - 6 } & 8 & 245.2 & 15.8 & 41.1 & 16.8 \\
\hline
\end{tabular}




\begin{tabular}{|c|c|c|c|c|c|}
\hline \multirow{6}{*}{$\mathrm{SBS}+\mathrm{PO}$} & 0 & 121.2 & 5.7 & 19.0 & 15.7 \\
\hline & $0\left(50^{\circ} \mathrm{C}\right)$ & 21.9 & 0.8 & 2.8 & 12.8 \\
\hline & 2 & 99.0 & 4.3 & 12.9 & 13.0 \\
\hline & 4 & 98.9 & 8.0 & 23.9 & 24.2 \\
\hline & 8 & 109.2 & 3.6 & 10.7 & 9.8 \\
\hline & $8\left(50^{\circ} \mathrm{C}\right)$ & 28.2 & 2.0 & 5.3 & 18.8 \\
\hline \multirow{6}{*}{$\mathrm{SBS}+\mathrm{OX}$} & 0 & 40.2 & 3.3 & 11.0 & 27.4 \\
\hline & $0\left(50^{\circ} \mathrm{C}\right)$ & 17.5 & 1.2 & 4.1 & 23.4 \\
\hline & 2 & 62.0 & 5.3 & 16.0 & 25.8 \\
\hline & 4 & 60.6 & 2.6 & 7.8 & 12.9 \\
\hline & 8 & 46.1 & 3.4 & 10.1 & 22.0 \\
\hline & $8\left(50^{\circ} \mathrm{C}\right)$ & 23.0 & 0.9 & 2.4 & 10.3 \\
\hline \multirow{6}{*}{$\mathrm{PO}+\mathrm{PO}$} & 0 & 114.0 & 11.4 & 34.1 & 29.9 \\
\hline & $0\left(50^{\circ} \mathrm{C}\right)$ & 24.2 & 0.5 & 1.6 & 6.8 \\
\hline & 2 & 109.6 & 3.5 & 10.4 & 9.5 \\
\hline & 4 & 122.0 & 6.9 & 20.6 & 16.9 \\
\hline & 8 & 141.6 & 8.2 & 24.6 & 17.4 \\
\hline & $8\left(50^{\circ} \mathrm{C}\right)$ & 31.4 & 0.2 & 0.6 & 2.0 \\
\hline \multirow{6}{*}{$\mathrm{PO}+\mathrm{OX}$} & 0 & 21.4 & 1.4 & 4.8 & 22.3 \\
\hline & $0\left(50^{\circ} \mathrm{C}\right)$ & 7.5 & 0.2 & 0.6 & 7.5 \\
\hline & 2 & 25.6 & 1.9 & 5.7 & 22.2 \\
\hline & 4 & 32.7 & 4.0 & 12.1 & 37.1 \\
\hline & 8 & 30.8 & 1.2 & 4.1 & 13.2 \\
\hline & $8\left(50^{\circ} \mathrm{C}\right)$ & 9.5 & 0.3 & 0.6 & 5.8 \\
\hline \multirow{6}{*}{$\mathrm{OX}+\mathrm{OX}$} & 0 & 32.4 & 2.1 & 7.0 & 21.5 \\
\hline & $0\left(50^{\circ} \mathrm{C}\right)$ & 18.1 & 0.4 & 1.5 & 8.2 \\
\hline & 2 & 35.6 & 2.6 & 6.8 & 19.2 \\
\hline & 4 & 34.4 & 2.5 & 7.5 & 21.9 \\
\hline & 8 & 32.5 & 1.0 & 3.4 & 10.4 \\
\hline & $8\left(50^{\circ} \mathrm{C}\right)$ & 17.0 & - & - & - \\
\hline
\end{tabular}

\section{Discussion}

With respect to the ageing process, all the joints for all the combinations gained strength at a temperature of $+23^{\circ} \mathrm{C}$; the only significant exception is the SBS+PO combination. However, even the strength in this combination increased in comparison to that of OX.

None of the joints lost strength at $50^{\circ} \mathrm{C}$. However, the strength of the $\mathrm{PO}+\mathrm{OX}$ combination is fairly low. The strength gains amounts to $50 \%$ of the total strength of the $\mathrm{OX}+\mathrm{OX}$ joint. This may be considered the critical strength.

The joints with combined strengths at $+23^{\circ} \mathrm{C}$ and $+50{ }^{\circ} \mathrm{C}$ shows results that are comparable with those of the non-combined strengths. The only exception is the SBS+PO 
combination at $23^{\circ} \mathrm{C}$. No substantial changes occur with regards to the different temperatures and the ageing process of the sample.

Owing to the poor workability of the bitumen sheets with the coating made from oxidized bitumen at $50^{\circ} \mathrm{C}$, the $\mathrm{PO}+\mathrm{OX}$ combination and the $\mathrm{OX}+\mathrm{OX}$ combination, only two bitumen sheets and one sample were tested.

The final strength of the SBS+PO joint is slightly lower than the strength of PO+PO joint despite the strength of SBS+SBS being ca. $100 \%$ higher than the strength of PO+PO. The result showed a slight degradation of the joint.

The final strength of the SBS+PO joint is higher than the strength of $\mathrm{OX}+\mathrm{OX}$ joint. The result did not indicate any degradation of the joint.

The final strength of the $\mathrm{PO}+\mathrm{OX}$ joint is lower than the strength of $\mathrm{OX}+\mathrm{OX}$ joint despite the strength of $\mathrm{OX}+\mathrm{OX}$ being ca. $25-30 \%$ of the $\mathrm{PO}+\mathrm{PO}$ strength. The result revealed a serious degradation of the joint.

The results of the laboratory testing suggest that the strength of the combination of the OX sheets with the SBS sheets and PO, is low. The peel resistance of the SBS+SBS and $\mathrm{PO}+\mathrm{PO}$ modifications does not meet the value requirements [2]; however, their values are higher than the results suggested in [3] and [5]. With regards to the plastomer sheets, the procedure [5] included a non-identifiable mass labelled APP. In contrast to the statements of the authors mentioned above, only the SBS+PO combination showed a sharp decrease in strength.

\section{Conclusion}

The results indicate that a combination of different masses of bitumen is a viable solution for the reconstruction and rehabilitation of roofs. However, consideration should be given to the right combination of the coating of bitumen. The results of the test show that it is possible to combine the SBS modified coating with a coating of oxidized bitumen or a PO modified coating. The combination with the coating from oxidized bitumen is considered hazardous for this kind of polymer because the strength of the joint is considerably lower than the strength of the AP joint with the coating from oxidized bitumen.

\section{References}

1. ČSN EN 12316-1, Flexible sheets for waterproofing - Part 1: Bitumen sheets for roof waterproofing - Determination of peel resistance of joints (2000)

2. M. Novotný, Střechy, fasády, izolace, 7, 44-45 (1999)

3. J. Plachý, Spoje asfaltovaných izolačních pásů za působení času a teploty ve skladbě jednopláštových plochých střech (Brno University of Technology, Brno, 2005)

4. J. Plachý, Collection of papers: Building Defects (2011)

5. R. Šmehyl, Pevnost' vzájemného spoja asfaltovaných povlakových krytín (Bratislava, 2007)

6. T. Petříček, Adheze spojů asfaltových pásů mechanicky kotvených (Brno University of Technology, Brno, 2013)

7. J. Stodůlka, Mechanicky kotvené povlakové hydroizolace (Brno University of Technology, Brno, 2014)

8. M. Novotný, I. Misar, S. Šutliak, Hydroizolace plochých střech. Poruchy střešních plášstơ (Grada, Prague, 2014) 